\title{
Analysis the Ability of Mathematic Connection With Cooperative Learning Model Thinking Pair Share and Thinking Pair Square
}

\author{
Miftakhul Jannah, Paridjo, Wikan Budi Utami
}

\author{
Study Program of Mathematics Education \\ Faculty of Teacher Training and Education \\ University of Pancasakti Tegal \\ miftakhuljannah96@gmail.com
}

\begin{abstract}
The study aims to determine the better mathematical connection capabilities between those taught using cooperative learning models of the type of Think Pair Share or Think Pair Square, and describe the mathematical connection ability of students taught by cooperative learning models of Think Pair Share and Think Pair Square types. The population in this study were all students of class VIII of SMP Negeri 2 Adiwerna in the academic year of 2017/2018. Quantitative samples use 2 experimental classes. While the qualitative sample is 12 high, medium and low ability students. Data collection was carried out quantitatively, namely by tests, and qualitative by observation, documentation, and interviews. The results of this study showed that the mathematical connection ability taught with the Think Pair Share type of cooperative learning model was better than Think Pair Square, the mathematical connection ability of students taught by Think Pair Share and Think Pair Square learning models was partly achieved by the low group students, medium, and high.
\end{abstract}

Keywords: Analysis, Mathematical Connection Ability, Cooperative Learning Model, Think Pair Share (TPS), Think Pair Square (TPSq)

\section{INTRODUCTION}

Mathematics is one of the subjects taught in school. The material learned in mathematics involves mathematical symbols and calculation of numbers. Therefore, mathematics is considered a subject that seems abstract by some students so it is difficult to understand. Based on the results of preliminary observations conducted by researchers, most of the eighth grade students of Adiwerna State Junior High School 2 considered mathematics subjects difficult. Researchers asked directly to the eighth grade students of Adiwerna State Middle School 2 regarding subjects that were considered difficult, almost all students answered math subjects. This can also be proven by the results of the semester 1 math UAS which are lower when compared with the value of other subjects.

One of the material taught in class VIII even semester is statistical material. Statistical material is not new material for class VIII students because this material has been studied in grade VI elementary school. Statistics is the study of how to analyze and process data. Statistics is not only used to process data in mathematics, but can be applied to process data outside the field of mathematics, such as calculating rainfall data, agricultural products data, population data, and others. Statistics is also very closely related to everyday life. So that in studying statistics there is a need for mathematical connection capabilities. According to Sugiman (2008: 56), in NCTM it is stated that there are five basic mathematical abilities, namely problem solving, reasoning and proof (reasoning and proof), communication (communication), connections (connections), and representation (representation). Mathematical connection ability is one component of five basic mathematical abilities because it is very much needed in mathematics learning. The mathematical connection ability connects mathematics to the 
experiences of students so that concepts in mathematics do not seem abstract and are easier for students to understand.

In an effort to improve quality human resources, educators and adequate infrastructure are needed during the learning process. Various learning models are applied by teachers in an effort to improve the ability of students. There are various kinds of learning models, one of which is the cooperative learning model. Cooperative learning model is done by dividing students into small groups that have different levels of ability. There are so many types of cooperative learning models, for example, are Think Pair Share and Think Pair Square learning models.

From its name, Think Pair Share and Think Pair Square learning models can be said to be almost similar. Both are types of cooperative learning models. Think Pair Square learning model is a modification of the Think Pair Share learning model. Both of these learning models provide opportunities for students to express their opinions or answers to their own thoughts, improve cooperation between students through discussion with their peers, and form students' confidence and activeness in presenting the results of the discussion. The difference is in the Think Pair Square learning model, after students discuss with their peers, then discuss again with the four groups.

Januartini, et al (2016) conducted a comparative study of Think Pair Square learning models and Think Pair Share on the motivation and learning outcomes of class X ICT students of SMA N 1 Sukasada. The results showed that there were higher average learning outcomes in students who used the cooperative learning model of Think Pair Square type compared to the cooperative learning model of Think Pair Share type on class X ICT subjects of SMA N 1 Sukasada in the 2015 school year / 2016

The source of previous research was conducted as an effort to clarify the variables used in this study, as well as to distinguish this research from previous research. The similarity in the study is the variable used, namely the researcher uses the cooperative learning model Think Pair Share and Think Pair Square as the independent variable and the mathematical connection ability of the students as the dependent variable. Whereas the difference is that the researcher analyzes the mathematical connection abilities of students with cooperative learning models of Think Pair Share and Think Pair Square.

The purpose of this study was to find out: (1) better mathematical connection skills between those taught using cooperative learning models of Think Pair Shar or Think Pair Square types. (2) mathematical connection abilities of students who are taught using the cooperative learning model type Think Pair Share. (3) the mathematical connection ability of students who are taught using the Think Pair Square cooperative learning model. Sugiman (2008: 65) said that mathematical connection ability is an ability that must be mastered by students in learning mathematics. According to Suherman (Lestari and Yudhanegara, 2017: 82-83), mathematical connection ability is the ability to associate mathematical concepts / rules with one another, with other fields of study, or with applications in the real world. Based on the above definition, it can be concluded that mathematical connection ability is the ability that must be mastered by students in applying relationships between mathematical topics, the relationship between mathematics and other fields of study, and the relationship between mathematics and everyday life.

Rusman (2016: 202) suggests that cooperative learning is a form of learning by means of students learning and working in small groups collaboratively with heterogeneous group structures. While Hosnan (2014: 234) argues that the cooperative learning model is a learning model that prioritizes the existence of groups. Every student in the group has different levels of ability (high, medium and low) and if possible group members come from different races, 
cultures, tribes and pay attention to gender equality. Based on several definitions above, it can be concluded that the cooperative learning model is a learning model that is carried out by forming small groups that have different abilities.

The Think Pair Share type cooperative learning model was first developed by Frank Lyman at the University of Maryland in 1981. Think Pair Share is one type of cooperative learning that stimulates thinking activities of students in pairs and sharing knowledge with other students (Lestari and Yudhanegara, 2017 : 52). According to Husna, et al (2013: 83), the cooperative learning model of the Think Pair Share type is a type of cooperative learning that is designed to influence students' interaction patterns.

The Think Pair Square (TPSq) type cooperative learning model was developed by Spencer Kagan in 1933. According to Lie (2014: 57), the Think Pair Square learning model is a learning model that gives students the opportunity to work alone and work with others. Januartini et al. (2016: 150) stated that the Think Pair Square learning model is a learning model that if a pair of students cannot solve the problem given, then another pair of students can explain how to answer it. If the problem raised does not have a correct answer, then two pairs can combine their results and form a more comprehensive answer. Based on the description, the researcher is interested in conducting research related to the analysis of students' mathematical connection skills with the cooperative learning model Think Pair Share (TPS) and Think Pair Square (TPSq) at Adiwerna 2 Public Middle School in the subject matter of statistics.

\section{RESEARCH METHOD}

The approach used in this study is a combination approach, which combines quantitative research with qualitative research. The quantitative approach is used to analyze data on students' mathematical connection abilities. While the qualitative approach is used to supplement the data and describe aspects of the quantitative approach. The research design used in this study is concurrent embedded design, which is a study that combines quantitative and qualitative research together, but the weight of the method is different.

The population taken in this study was the eighth grade students of Adiwerna 2 Public Middle School in the academic year 2017/2018 which consisted of 9 classes as many as 313 students. Sampling in this study uses 2 sampling techniques. To obtain quantitative data using simple random sampling technique, the samples taken were class VIII E as experimental class 1 as many as 34 students, class VIII D as experimental class 2 as many as 34 students, and class VIII $F$ as the pilot class as many as 36 students. Whereas to obtain qualitative data using purposive sampling technique, it was obtained 2 low group students, 2 moderate group students, and 2 high group students for each experimental class 1 and 2. Experimental class 1 qualitative research sample namely subject EP-21, EP-23, EP-17, EP-29, EP07, EP-19. While the qualitative research sample for experimental class 2 is the subject ER-10, ER-11, ER-30, ER-31, ER-29, ER-34.

Quantitative data collection is a mathematical connection ability test using cooperative learning model Think Pair Share (TPS) in class VIII E and Think Pair Square (TPSq) in class VIII D. While qualitative data collection is by observing the teaching process conducted by researchers, observation mathematical connection skills of students, interviews with eighth grade mathematics teachers, interviews with students, documentation in the form of odd semester UAS math scores, data on the number of all eighth grade students of Adiwerna State Middle School 2, list of names of students used as samples, and the results of the photos during the learning process take place.

\section{RESULT AND DISCUSSION}

The results of quantitative research were obtained from the value data of the mathematical connection ability which then carried out hypothesis testing using the $t$ test of the right side. Before hypothesis testing is carried out, a prerequisite test for the hypothesis is first, namely the normality test and homogeneity test. Based on the prerequisite tests that have been carried out, 
it is known that the data on mathematical connection ability of experimental class 1 students and experimental class 2 are normal and homogeneous. The results of the SPSS output from the right one $t$ test can be seen in the table below: Table 1. Results of the SPSS Output Test for the Right One-t Test

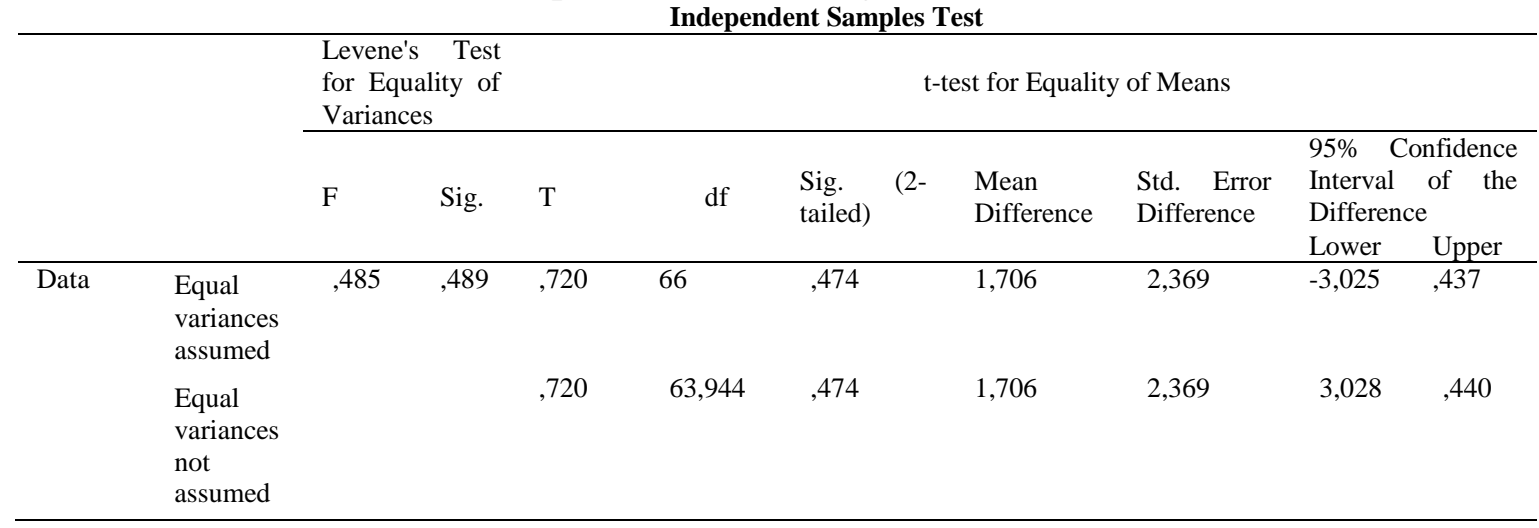

Testing the right one $\mathrm{t}$ is known from the Sig. (2-tailed) in the t-test for Equality of Means table of 0.474 . Because the test is a one-party test (right-hand test), the Sig $=\frac{1}{2} \times$ nilai Sig. $(2-$ tailed $)=\frac{1}{2} \times 0,474=0,237$. Therefore, the value of $\alpha$ chosen is also $\frac{1}{2} \alpha=$ $\frac{1}{2}(0.05)=0.025$. Because the Sig value is greater than $\frac{1}{2} \alpha$, then $\mathrm{H}_{0}$ is accepted. In addition, the value of $t_{\text {count }}=0,720$ while $t_{\text {tabel }}=1,668$. Because $t_{\text {count }}<t_{\text {tabel }}$, then $H_{0}$ is accepted. Thus, it can be concluded that mathematical connection skills taught using Think Pair Square cooperative learning models are no better than Think Pair Share.

However, Januartini, et al. (2016) conducted a comparative study of Think Pair Square learning models and Think Pair Share on motivation and learning outcomes of students of ICT learning class $\mathrm{X}$ at SMA N 1 Sukasada that there were higher average learning outcomes for students who using cooperative learning learning models Think Pair Square compared to cooperative learning learning types Think Pair Share. Mathematical connection ability is part of student learning outcomes so this is different from the presumption that mathematical connection skills taught by Think Pair Square type cooperative learning models are better than Think Pair Share.

Based on observations made to observe the researcher as a teacher, it shows that the learning process has been carried out in accordance with the steps of the learning model. However, at the pairing stage, the researcher forms a pair of groups according to the seat. Forming groups in pairs according to seating is intended to save time. But this can cause students to pair in a homogeneous or heterogeneous manner. In experimental class 1 taught by Think Pair Share learning models, groupings that occur homogeneously can be anticipated at the sharing stage. At the sharing stage, students present the results of their discussion in front of the class, so that if they cannot solve the problem given, they will be assisted by their classmates. In contrast to students who are taught with Think Pair Square learning models, after discussing with groups in pairs, discuss again with the four groups. In the square (four) stage, the possibility of forming a homogeneous group can also occur. Therefore it can be concluded that mathematical connection skills taught by Think Pair Share cooperative learning models are better than Think Pair Square.

Qualitative data is obtained from the results of data reduction, namely collecting data from observations, interviews, and documentation, then selecting important data and discarding unused data. The next stage is the presentation of data, which is looking for the relationship 
between the data from observations, interviews, and documentation, then presents the data into a relationship pattern in the form of a brief description. The final stage of conclusions is making conclusions in the form of new findings from the results of data presentation, then constructing these conclusions into the research title.

Based on the observation results of mathematical connection abilities taught by the cooperative learning model of Think Pair Share type, it shows that the indicators of mathematical connection ability that is applying relationships between mathematical topics can be applied by subject EP-17, EP-29, EP-07, and EP-19 . Indicators of mathematical connection ability that is applying the relationship of mathematics to everyday life can be applied by subjects EP-07 and EP-19. Indicators of mathematical connection ability, namely applying the relationship between mathematical topics and topics outside mathematics, can be applied by subjects EP-17, EP-29, EP-07, and EP-19.

Based on the results of interviews with students after learning with the Think Pair Share learning model, EP-21 subjects still have relatively low mathematical connection skills because there are no indicators of mathematical connection abilities that he mastered. Subject EP-23 has a relatively low mathematical connection ability because it is only one indicator of mathematical connection ability that he mastered. Subject EP-17 has a relatively low mathematical connection ability because it is only one indicator of mathematical connection ability that he mastered. Subject EP-29 has a relatively moderate mathematical connection ability because there are only two indicators of mathematical connection ability that he mastered. Subject EP-07 has a relatively high mathematical connection ability because he can master all three indicators of mathematical connection ability. Subject EP-19 has a relatively moderate mathematical connection ability because only two indicators of mathematical connection ability are mastered.

Therefore, it can be concluded that the indicators of students' mathematical connection abilities taught by the Think Pair Share learning model can be partially achieved by low, medium and high group students. Based on the observation results of mathematical connection abilities taught by the cooperative learning model of Think Pair Square type, it shows that the indicator of mathematical connection ability that is applying relationships between mathematical topics can be applied by the subjects ER-10, ER-11, ER-30, ER-31, ER-29, and ER-34. Indicators of mathematical connection ability, namely applying the relationship of mathematics to everyday life can be applied by the subjects ER-30, ER-31, ER-29, and ER-34. Indicators of mathematical connection ability, namely applying the relationship between mathematical topics and topics outside mathematics can be applied by the subjects ER-30, ER31, ER-29, and ER-34.

Based on the results of interviews with students after learning with the Think Pair Square learning model, the ER-10 subject had relatively low mathematical connection ability because it was only one indicator of mathematical connection ability that he mastered. ER-11 subjects have relatively low mathematical connection ability because there is no indicator of mathematical connection ability that he mastered. ER-30 subjects have relatively low mathematical connection ability because they are only one indicator of mathematical connection ability that they master. ER-31 subjects have relatively low mathematical connection ability because they are only one indicator of mathematical connection ability that he mastered. ER-29 subjects have relatively moderate mathematical connection skills because only two indicators of mathematical connection ability are mastered. ER-34 subjects have relatively moderate mathematical connection ability because only two indicators of mathematical connection ability are mastered. Therefore, it can be concluded that the indicators 
of students' mathematical connection abilities taught by the Think Pair Square learning model can be partially achieved by low, medium and high group students.

\section{CONCLUSION}

Based on the results and discussion, it can be concluded that the mathematical connection skills taught using the Think Pair Share (TPS) type cooperative learning model are better than Think Pair Square (TPSq) and the students' mathematical connection skills are taught using Think Pair Share (TPS) learning models. ) and part of Think Pair Square (TPSq) can be achieved by low, medium and high group students. Based on the conclusions above, the suggestion that researchers can recommend is that teachers should form heterogeneous pairing groups if they apply the cooperative learning type Think Pair Share and Think Pair Square models, students should improve their mathematical connection skills so that mathematics becomes easier and does not seem abstract, participants students should be active during the learning process, because it has a positive effect on improving mathematical connection skills.

\section{REFERENCES}

Badjeber, R., \& Fatimah, S. (2015). Peningkatan Kemampuan Koneksi Matematis Siswa SMP melalui Pembelajaran Inkuiri Model Alberta. Jurnal Pengajaran MIPA. Online. Vol. 20
$(1)$,
18-26,
diakses
11 Desember
2017
dari http://journal.fpmipa.upi.edu/index.php/jpmipa/article/view/557.

Erra, U., \& Scanniello, G. (2011). Assessing Think-Pair-Square in Distributed Modeling of Use Case Diagrams. In Empirical Requirements Engineering (EmpiRE), 2011 First Internasional Workshop on (pp. 77-84). IEEE, diakses 14 Desember 2017 dari http://ieeexplore.ieee.org/document/6046249/.

Eviliyanida, E. (2011). Model Pembelajaran Kooperatif. Jurnal Visipena. Online. Vol. 2 (1), 21-27, $\quad$ diakses $\quad 10 \quad$ Januari 2018 dari http://visipena.stkipgetsempena.ac.id/home/article/view/19.

Fajri, N. (2015). Korelasi antara Kemampuan Koneksi dan Komunikasi Matematis Siswa dengan Menggunakan Pendekatan Contextual Teaching and Learning (CTL). Jurnal Numeracy. Online. Vol. 2 (1), 51-60, diakses 11 Desember 2017 dari http://numeracy.stkipgetsempena.ac.id/home/article/view/16.

- (2016). Analisis Kemampuan Koneksi dan Komunikasi Matematis Mahasiswa Pendidikan Matematika: Studi Kualitatif pada Mahasiswa Pendidikan Matematika STKIP Bina Bangsa Getsempena Kota Banda Aceh, Aceh. Jurnal Numeracy. Online. Vol. 3 (2), 23-30, diakses 11 Desember 2017 dari http://numeracy.stkipgetsempena.ac.id/home/article/view/40.

Hosnan, M. (2016). Pendekatan Saintifik dan Kontekstual dalam Pembelajaran Abad 21. Bogor: Ghalia Indonesia.

Husna, M., Ikhsan, \& Fatimah, S. (2013). Peningkatan Kemampuan Pemecahan Masalah Dan Komunikasi Matematis Siswa Sekolah Menengah Pertama melalui Model Pembelajaran Kooperatif Tipe Think-Pair-Share (TPS). Jurnal Peluang. Online. Vol. 1 (2), 81-92, diakses $\quad 11 \quad$ Desember 2017 dari http://www.jurnal.unsyiah.ac.id/peluang/article/view/1061.

Januartini, P. D., Agustini, K., \& Sindu, I. G. P. (2016). Studi Komparatif Model Pembelajaran Think Pair Square dan Think Pair Share terhadap Motivasi dan Hasil Belajar Siswa Mapel TIK Kelas X SMA N Sukasada. Jurnal Pendidikan Teknologi dan Kejuruan. Online. Vol. 13 (2), 148-160, diakses 11 Desember 2017 dari http://ejournal.undiksha.ac.id/index.php/JPTK/article/view/8523. 
Kementerian Pendidikan dan Kebudayaan. (2016). Buku Guru Mata Pelajaran Matematika. Jakarta: Kementerian Pendidikan dan Kebudayaan.

Lestari, K. E. dan Yudhanegara, M. R. (2017). Penelitian Pendidikan Matematika. Bandung: Refika Aditama.

Lie, A. (2014). Cooperative Learning: Mempraktikkan Cooperative Learning di Ruang-Ruang Kelas. Jakarta: Gramedia.

Miftah, R. (2014). Pengaruh Pembelajaran Kooperatif Tipe Think Pair Share terhadap Kemampuan Koneksi Matematis Peserta didik. Innovation in mathematics education toward asian community: Prosiding Seminar Nasional Pendidikan Matematika 2014. Jakarta: UHAMKA Press.

Mufidah, L., Dzulkifli, E., \& Titi, T. (2013). Penerapan Model Pembelajaran Kooperatif Tipe TPS untuk Meningkatkan Aktivitas Belajar Siswa pada Pokok Bahasan Matriks. Jurnal Pendidikan Matematika STKIP PGRI Sidoarjo. Online. Vol. 1 (1), 117-125, diakses 14 Desember $2017 \quad$ dari http://lppm.stkippgrisidoarjo.ac.id/index.php?pilih=mat\&modul=yes\&action=detail\&id=c20ad4d 76fe 9775 9aa27a0c99bff6710.

Nasution, Y. S., \& Surya, E. (2017). Application of TPS Type Cooperative Learning in Improving Students' Matematics Learning Outcomes. Internasional Journal of Sciences (IJSBAR). Online. Vol. 34 (1), 116-123, diakses 14 Desember 2017 dari http://gssrr.org/index.php?journal=JournalOfBasicAndApplied.

Priansa, D. J. (2017). Pengembangan Strategi \& Model Pembelajaran. Bandung: CV Pustaka Setia.

Pusat Bahasa. (2008). Kamus Besar Bahasa Indonesia Pusat Bahasa. Jakarta: PT Gramedia Pustaka Utama.

Rinawati. (2014). Analisis Butir Soal Matematika pada Ulangan Tengah Semester Genap berdasarkan Item Response Theory (IRT). Skripsi Universitas Pancasakti Tegal: tidak diterbitkan.

Rusman. (2016). Model-model Pembelajaran: Mengembangkan Profesionalisme Guru. Jakarta: Raja Grafindo Persada.

Shoimin, A. (2014). 68 Model Pembelajaran Inovatif dalam Kurikulum 2013. Yogyakarta: ArRuzz Media.

Siregar, N. D., \& Surya, E. (2017). Analysis of Students'Junior High School Mathematical Connection Ability. International Journal of Sciences:Basic and Applied Research (IJSBAR). Online. Vol. 33(02), 309-320, diakses 10 Januari 2018 dari http://gssrr.org/index.php?journal=JournalOfBasicAndApplied.

Sholikhah, Z., Kartana, T. J., \& Utami, W. B. (2018). Efektifitas Model Pembelajaran OpenEnded terhadap Prestasi Belajar Matematika Ditinjau dari Kreativitas Siswa. JES-MAT (Jurnal Edukasi dan Sains Matematika). Online. Vol. 4 (1), 35-46, diakses 30 Maret 2018 dari http://journal.uniku.ac.id/.

Sugiman. (2008). Koneksi Matematik dalam Pembelajaran Matematika di Sekolah Menengah Pertama. Pythagoras: Jurnal Pendidikan Matematika. Online. Vol. 4 (1), diakses 12 Desember 2017 dari https://journal.uny.ac.id/index.php/pythagoras/article/view/687.

Sugiyono. (2012). Statistika untuk Penelitian. Bandung: Alfabeta. . (2017). Metode Penelitian Kombinasi (Mixed Methods). Bandung: Alfabeta.

Susongko, P. (2016). Penilaian Hasil Belajar. Tegal: Badan Penerbit Universitas Pancasakti Tegal.

Wara, M., Rizal, Y., dan Nilaswati. (2012). Model Cooperative Learning Tipe Think Pair Square dalam Pembelajaran Matematika di Kelas VII SMPN 1 Pulau Punjung. Jurnal 
Pendidikan Matematika. Online. Vol. 1 (1), diakses 11 Desember 2017 dari http://ejournal.unp.ac.id/students/index.php/pmat/article/view/1157 